\title{
Challenge Agent Multiple Route Indicator
}

National Cancer Institute

\section{Source}

National Cancer Institute. Challenge Agent Multiple Route Indicator. NCI Thesaurus.

Code C158371.

An indication as to whether the challenge agent is administered by more than one route for any animal(s). 